\title{
RESPONSE OF TUBEROSE PLANTS (POLIANTHES TUBEROSA L.) TO CHEMICAL AND BIO FERTILIZATION AND THEIR EFFECT ON VEGETATIVE GROWTH, FLOWERING AND CHEMICAL COMPOSITION UNDER SANDY SOIL CONDITIONS
}

\author{
K.E. Attia ; Naglaa F.S. Elbohy ${ }^{* *}$ and Nahla A.M. Ashour ${ }^{*}$ \\ * Medicinal and Aromatic Plants Res. Dept., Hort. Res. Inst., ARC, Egypt. \\ ** Ornamental Plants and Landscape Gardening Res. Dept., Hort. Res. Inst., ARC, Egypt.
}

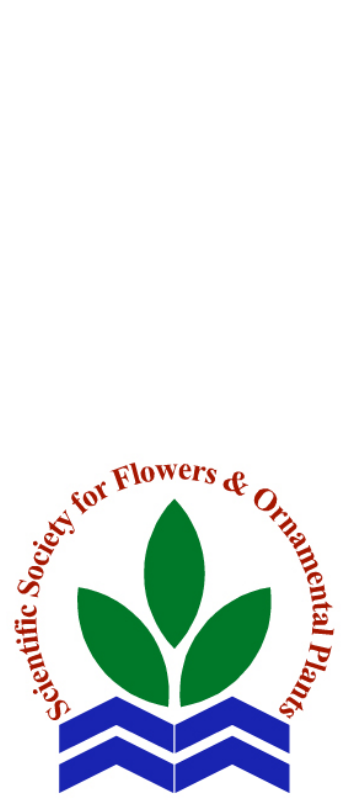

ABSTRACT: A field experiment was carried out at the Experimental Farm of El-Kassasin Horticultural Research Station, Agricultural Research Center, Ismailia Governorate, Egypt, to study the effect of partial substitution of chemical nitrogen fertilizer with biofertilizer containing two strains of nitrogen-fixing (Azospirillum lipoferum, Azotobacter chrococcoum), on vegetative growth, flowering and chemical composition of tuberose plants (Polianthes tuberosa L.) under sandy soil conditions to rationalize the use of mineral fertilizers and reduce pollution of the environment in order to increase the quantity and improvement quality of the product on the tuberose plants during the two successive seasons of 2017 and 2018. This experiment included seven treatments with three replications, which were the combinations between two of mineral nitrogen rates (50\% and $75 \%$ ) and three bio-fertilizers of nitrogen-fixing bacteria (Azospirillum lipoferum (S), Azotobacter chrococcoum (Z) and Azospirillum lipoferum + Azotobacter chrococcoum ( $\left.\mathrm{S}^{*} \mathrm{Z}\right)$ treatments in addition to the control which was $100 \% \mathrm{~N}$. The treatments were arranged in

Scientific J. Flowers \& Randomized Complete Block Design. The results showed that Ornamental Plants, fertilizing tuberose plants with mineral nitrogen at $100 \%$ of the 5(3):261-273 (2018).

Received:

16/9/2018

Accepted:

25/9/2018 recommended dose recorded the highest values for plant height, number of leaves/plant and number of florets/spike. while fertilization with mineral nitrogen at $75 \%$ plus the dual inoculation with Azospirillum + Azotobacter recorded the highest values for fresh and dry weights of leaves (g)/plant, fresh and dry weights of root (g)/plant, fresh and dry weights of spike (g)/plant, floret diameter $(\mathrm{cm})$, spike length $(\mathrm{cm})$, longevity of tuberose cut flower spikes (days), in addition to leaves content of $\mathrm{N}, \mathrm{P}, \mathrm{K}$, total chlorophyll a, b and carbohydrates $\%$, as well as essential oil percentage in flowers without significant difference between them and control in most cases in both seasons.

Key words: Tuberose, Spike, Nitrogen, Bio-fertilizers, Azospirillum and Azotobacter.

\section{INTRODUCTION}

Polianthes tuberosa L. is a perennial bulbous plant of the Agavaceae family, and is an ornamental bulb plant native to Mexico (Benschop, 1993). It has a good economic potential for cut flower trade and essential oil industry (Alan et al., 2007). Tuberose is one of the common cultivated flowering bulbs used as garden plant with a great demand for its attractive tall spikes with fragrant cut flowers and also for extraction of 


\section{K.E. Attia et al.}

its highly valued natural flower essential oils (Jawaharlal et al., 2006). In France and India, tuberose plant was widely cultivated as a source of essential oils for the perfume industry (Majid et al., 2012).

Tuberose also responses well to the application of mineral fertilizers, which are observed to be varying depending on the climatic condition and soil types. Nitrogen, phosphorus and potassium markedly influence the growth and development of plants. However, reliance on chemical fertilizers increases soil and environmental pollution (Qureshi, 2007). Patel (2005) stated that, application of nitrogen at 400 $\mathrm{kg} / \mathrm{ha}$ on tuberose significantly recorded the highest values of vegetative, floral and quality characters viz., plant height, number of leaves, number of days to first flowering, spike length, number of florets/spike and diameter of floret. Also, Khalaj et al. (2012) showed that using $200 \mathrm{~kg} / \mathrm{ha} \mathrm{N}$ can improve growth and yield characters of tuberose as flower stalk height, stem diameter, bulb weight, chemical constituents (chlorophyll a, b and carotenoids contents and N, P, K percentages of leaves. Recently, Kumar et al. (2017, whereas, maximum plant height, number of leaves, fresh and dry weights of leaves, spike length, rachis length, number of florets per spike and vase life was recorded with $\mathrm{N}_{2}$ (60 kg/acre nitrogen). In this regard, the maximum plant height and number of leaves per clump of tuberose were observed by nitrogen at $20 \mathrm{~g} / \mathrm{m}^{2}$ (Nain et al., 2018).

In the recent years, the safe agriculture is one of the main attitudes in the world (ElKouny, 2002). Bio-fertilizers are reasonably safer to the environment than chemical fertilizers and play an important role in decreasing the use of chemical fertilizers. Consequently, it causes a reduction in environmental pollution. Soil inoculation with micro-organisms lead to increase soil available nitrogen and consequently increase formation of metabolites which encourage the plant vegetative growth and enhance the meristematic activity of tissues to produce more branches. Also, N-fixers synthesize stimulatory compounds such as gibberellins, cytokinins and IAA that act as growth regulators (Sperenat, 1990 and Dadarwal et al., 1997). Barman et al. (2003) studied the effect of biofertilizers, alone or with other fertilizers, on the growth and yield of tuberose (Polianthes tuberosa) results showed that, plant height and spike emergence were significantly enhanced with Bacillus firmus inoculation compared to the untreated control. Attia et al. (2005) studied the response of chemical constituents of Gladiolus grandiflorus, L. "Eurovision" to different N-fixing bacteria treatments, they found that chemical constituents (chlorophyll $\mathrm{a}, \mathrm{b}$ and carotenoids contents, N, P, K percentages of leaves and corms and reducing sugars content in the leaves and corms) were significantly augmented as a result of using the different $\mathrm{N}$-fixing bacteria treatments, and the most effective treatment in this respect was the dual strain (Azotobacter chroococcum and Azospirillum brasilense). Kandeel et al. (2002) on Ocimum basilicum L. plant found that dual inoculation with symbiotic $\mathrm{N}_{2}$ fixers (Azotobacter and Azospirillum) with half or full doses of inorganic $\mathrm{N}$ fertilizer increased plant height, number of branches per plant, and fresh and dry weights of leaves as well as roots. Also Ali et al. (2014) reported that application of biofertilizers to gladiolus showed that all vegetative and reproductive growth accomplished successfully, however, the treatment containg Azospirillum gained highest values in terms of plant height, florets spike, spike length, florets fresh weight and vase life.

Therefore the aim of the present study was to clarify the effect of partial substitution of chemical nitrogen fertilizer by inoculation with Azospirillum lipoferum and Azotobacter chrococcoum on growth, flowering and chemical composition of tuberose plants under sandy soil conditions to rationalize the use of mineral fertilizers and reduce pollution of the environment in order to increase the quantity and to improve quality of the product of tuberose plants. 


\section{MATERIALS AND METHODS}

Afield experiment was carried out at the Experimental Farm of El-Kassasin Horticultural Research Station, Ismailia Governorate, Egypt, during the two successive seasons of 2017 and 2018.

\section{Plant material:}

Bulbs of tuberose with $30-35 \mathrm{~mm}$ diameter (about 25 - 35 g weight) were obtained from a private farm at El Qanatir El Khaireya, Qualubya Governorate, Egypt.

The physical and chemical properties of the experimental soil used in this experiment are showen in Table (1). While the dry compost was added to the experimental area during preparing soil before planting in the two seasons as a rate of 10 tons/fed and the analysis of the used compost was recorded in Table (2).

Table 1. The physical and chemical properties of the experimental soil in the two seasons.

\begin{tabular}{llll}
\hline \multicolumn{3}{l}{ Physical characteristics Chemical characteristics } \\
Field capacity & 11.77 & $\mathrm{CaCO}_{3} \%$ & 12.25 \\
\multicolumn{2}{|l}{ Available water 7.57} & Organic matter \% & 0.08 \\
Wilting point & 4.20 & $\mathrm{pH}$ & 7.5 \\
Coarse sand & 73.08 & $\mathrm{EC} \mathrm{(ds/m)}$ & 2.14 \\
Fine sand & 15.7 & $\mathrm{Ca}(\mathrm{mg} / 100 \mathrm{~g})$ & 0.14 \\
Silt & 7.2 & $\mathrm{Na}(\mathrm{mg} / 100 \mathrm{~g})$ & 0.34 \\
Clay & 4.02 & $\mathrm{~K}(\mathrm{mg} / 100 \mathrm{~g})$ & 0.16 \\
Texture class & Sandy & $\mathrm{Cl}(\mathrm{mg} / 100 \mathrm{~g})$ & 0.30 \\
\hline
\end{tabular}

Table 2. Compost analysis.

\begin{tabular}{llll}
\hline Fresh weight & $750-850 \mathrm{~kg}$ & \multicolumn{2}{l}{ Macro elements (\%) } \\
Dry weight $\left(\mathrm{m}^{3}\right)$ & $550-650 \mathrm{~kg}$ & $\mathrm{~N} \%$ & $0.8-1.2$ \\
Moisture \% & $25-30 \%$ & $\mathrm{P} \%$ & $0.4-0.6$ \\
$\mathrm{pH}$ & $7.5-8.5$ & $\mathrm{~K} \%$ & $0.8-1.4$ \\
EC ds/m & $3.5-6.5$ & \multicolumn{2}{l}{ Micro elements (ppm) } \\
Saturation \% & $150-200$ & $\mathrm{Fe}$ & $1000-1800$ \\
Organic matter $\% 25-30$ & $\mathrm{Mn}$ & $80-120$ \\
Organic carbon & $14.5-17.5$ & $\mathrm{Cu}$ & $100-160$ \\
C/N ratio & $1: 14.5$ or $1: 18 \mathrm{Zn}$ & $30-50$ \\
\hline
\end{tabular}

\section{Chemical nitrogen fertilizer:}

The nitrogen fertilizer used was ammonium nitrate $33.5 \% \mathrm{~N}$, and the recommended dose of this fertilizer was 80 $\mathrm{kg} \mathrm{N} /$ fed. The treatments of this factor were [ $100 \%$ as a control, $75 \%$ (60 Kg N/fed) and $50 \%$ (40 kg/fed) from the recommended dose]. Nitrogen fertilizer was divided to four equal portions and was added after 30, 45, 60 and 75 days from sowing.

\section{Microorganisms:}

Microorganisms bacteria used [Azospirillum lipoferum (S) and Azotobacter chrococcoum (Z)] were obtained from Microbiology Department, Soil Water and Environment Research Institute, Agric. Res. Center (ARC), Giza, Egypt. The $\mathrm{N}_{2}$-fixers inoculum (1 $\mathrm{kg} / \mathrm{fed})$ was mixed with tuberose bulbs by adding Arabic gum solution, then bulbs coated with the inoculum before sowing and the treated bulbs were directly sown in the same day.

\section{The arrangement of treatments:}

This experiment included seven treatments with three replications, which were the combinations between two of mineral nitrogen rates (50\% and $75 \%$ ) and three bio-fertilizers of nitrogen-fixing bacteria ( $\mathrm{S}, \mathrm{Z}$ and $\mathrm{S} \mathrm{Z}$ ) treatments in addition to the control which was $100 \% \mathrm{~N}$. The treatments were arranged in Randomized Complete Block Design as simple experiment, as follow:

1. $50 \% \mathrm{~N}+$ Azospirillum lipoferum (S).

2. $50 \% \mathrm{~N}+$ Azotobacter chrococcoum (Z).

3. $50 \% \mathrm{~N}+$ Azospirillum lipoferum + Azotobacter chrococcoum (S*Z).

4. $75 \% \mathrm{~N}+$ Azospirillum lipoferum (S).

5. $75 \% \mathrm{~N}+$ Azotobacter chrococcoum (Z).

6. $75 \% \mathrm{~N}+$ Azospirillum lipoferum + Azotobacter chrococcoum (S*Z).

7. Control $(100 \% \mathrm{~N})$.

\section{Cultivation procedures:}

The bulbs were planted in the $10^{\text {th }}$ April, for the two seasons. The bulbs were planted on rows, at $30 \mathrm{~cm}$ between plants in 
the row (23300 bulbs per feddan). The experimental unit area was $9 \mathrm{~m}^{2}$ it contained three rows with $5 \mathrm{~m}$ in length and $60 \mathrm{~cm}$ in width.

\section{Harvesting stage:}

The spikes were harvested when 2-3 pairs of florets from the bottom of the spike opened. The individual spike was harvested by cutting it from the bottom.

\section{Holding solution treatment:}

From all treatments tuberose cut flower spikes were held till the end of the experiment in holding solution which was composed of sucrose (S) + 8-hydroxylquinoline sulphate (8-HQS) + citric acid (CA) $[\mathrm{S}+8-\mathrm{HQS}+\mathrm{CA}]:$ at 4\%, $400 \mathrm{ppm}$ and $100 \mathrm{ppm}$ concentrations, respectively. The $\mathrm{pH}$ of holding solution was 3.45.

\section{Data recorded:}

The following characters were recorded:

\section{Vegetative characters:}

\section{Records were taken at flowering stage as for:}

1. Plant height $(\mathrm{cm})$.

2. Number of leaves/plant.

3. Fresh and dry weights of leaves (g)/plant.

4. Fresh and dry weights of root (g)/plant.

\section{Floral characters:}

1. Number of florets/spike.

2. Floret diameter $(\mathrm{cm})$ in tuberose spike from 2 pair of florets from the bottom of the spike opened.

3. Fresh and dry weights of spike (g)/plant.

4. Spike length $(\mathrm{cm})$.

\section{Postharvest characters:}

Longevity of tuberose cut flower spikes (days) was determined when the wilted florets reach $75 \%$ from the number of the total florets on the spikes according to ElSaka (1992) on tuberose cut flower spikes.

\section{Chemical characters:}

1. Total nitrogen, phosphorus and potassium percentages in leaves were determined according to the procedure described by Mazumder and Majumder (2003).

2. Chlorophyll a and b: fresh leaf samples were taken for measuring the chlorophyll $\mathrm{a}$ and $\mathrm{b}$ according to Mazumder and Majumder (2003).

3. Total carbohydrates \% (d.w.) were determined according to Herbert et al. (2005).

4. Essential oil percentage extraction: Hexane was used as solvent to extract the scents from tuberose flowers because it is strongly non-polar solvent and is frequently used insolvent to extract oils. $100 \mathrm{~g}$ of flowers were soaked in 1 liter of solvent for $1 \mathrm{~h}$. After removing the debris, the solvent was evaporated leaving the concrete behind. Tuberose absolute was extracted from concrete sample using alcohol according to Rakthaworn et al. (2009).

\section{Statistical analysis:}

The statistical analysis of the present data was carried out according to Steel and Torrie (1980) using L.S.D. at 5\% and 1\% levels for comparison between means of the different treatments.

\section{RESULTS AND DISCUSSION}

\section{Vegetative growth:}

\section{Plant height:}

Data presented in Table (3) show the effect of nitrogen fertilization rates and biofertilizers on plant height of tuberose. It is obvious from the data that, fertilizing tuberose plant with $100 \%$ mineral nitrogen (control) significantly was the superior treatment for increasing plant height followed by fertilization with mineral nitrogen at $75 \%$ plus the dual inoculation 
Table 3. Effect of nitrogen fertilizer rates and bio-fertilizer kinds on plant height and number of leaves/plant of tuberose plants during the two seasons.

\begin{tabular}{|c|c|c|c|c|}
\hline & \multicolumn{2}{|c|}{ Plant height (cm) } & \multicolumn{2}{|c|}{ No. of leaves/plant } \\
\hline & $1^{\text {st }}$ season & $2^{\text {nd }}$ season & $1^{\text {st }}$ season & $2^{\text {nd }}$ season \\
\hline $50 \% N+S$ & 55.3 & 59.3 & 32.7 & 33.7 \\
\hline $50 \% N+Z$ & 61.3 & 63.7 & 34.3 & 38.0 \\
\hline $50 \% N+S * Z$ & 65.3 & 68.3 & 37.3 & 41.3 \\
\hline $75 \% \mathrm{~N}+\mathrm{S}$ & 72.7 & 73.7 & 55.7 & 59.7 \\
\hline $75 \% N+Z$ & 74.3 & 75.3 & 57.7 & 62.0 \\
\hline $75 \% N+S * Z$ & 81.0 & 82.3 & 58.7 & 64.3 \\
\hline $100 \% \mathrm{~N}$ & 81.3 & 82.0 & 59.7 & 66.3 \\
\hline LSD. at $5 \%$ & 1.1 & 0.8 & 1.7 & 1.9 \\
\hline LSD. at $1 \%$ & 1.5 & 1.1 & 2.4 & 2.7 \\
\hline
\end{tabular}

$\mathrm{N}=$ nitrogen, $\mathrm{S}=$ Azospirillum lipoferum, $\mathrm{Z}=$ Azotobacter chrococcoum and $\mathrm{S} * \mathrm{Z}=$ Azospirillum lipoferum + Azotobacter chrococcoum.

Azospirillum + Azotobacter without significant differences between them. On the contrary, the lowest values in this connection were reported generally in case of $50 \%$ mineral nitrogen plus inoculation with Asospirillum in both seasons.

The increment in plant height due to the application of high rate mineral $\mathrm{N}(80 \mathrm{~kg}$ $\mathrm{N} /$ fed) may be attributed to the pronounced role of nitrogen in plant metabolism. Nitrogen is a constituent of proteins, enzymes, hormones, vitamins, chlorophyll and photosynthesis which led to an increase in plant metabolism and vegetative growth (Reddy and Reddi, 2002), while the favorable effect of biofertilizer on vegetative growth could be attribute to the activity of bacteria in the absorption zone of plant root by improving soil fertility and consequently plant development by $\mathrm{N}_{2}$-fixation and due to releasing of certain other nutrients; i.e., Fe, $\mathrm{Zn}$, and Mn (Bhonde et al., 1997) through the breakdown of organic materials in the soil and make these elements in available forms.

\section{Number of leaves/plant:}

Regarding the effect of mineral nitrogen fertilization rates and biofertilizers on number of leaves of tuberose plants, the data illustrated in Table (3) reveal that, the highest value recorded with the treatment of $100 \%$ mineral nitrogen followed by mineral nitrogen at $75 \%$ plus the dual inoculation Azospirillum + Azotobacter with no significant difference between them in the first season and with a significant difference in the second one. Furthermore, the differences between the combined treatment of mineral nitrogen at $75 \%$ plus the dual inoculation Azospirillum + Azotobacter and other treatments were highly significant.

Similarly, the effect of nitrogen fertilizer on number of leaves of tuberose was studied by (Nain et al., 2018). While Increasing plant growth due to free living $\mathrm{N}$ fixating bacteria such as Azotobacter, Azospirillum, Bacillus polymixa, Enterobacter and Klebsiela were found to have not only the ability to fix nitrogen but also to release certain phytohormon of gibberlic and indolic nature compounds which could stimulate plant growth, absorption of nutrients and photosynthesis process (Fayez et al., 1985).

\section{Fresh weight of leaves (g)/plant:}

Data in Table (4) show the effect of mineral nitrogen fertilization rates and biofertilizers on fresh weight of leaves/plant of tuberose. The treatments had clear influences on the fresh weight. The differences between majority of treatments were highly significant. The superior effect obtained from the combined treatment of mineral nitrogen at $75 \%$ plus the dual inoculation Azospirillum + Azotobacter, followed by control $(100 \% \mathrm{~N})$, with highly significant effects during both seasons. The aforementioned results also were in harmony with those obtained by Patel (2005) on tuberose and Attia et al. (2005) on Gladiolus grandiflorus. 
Table 4. Effect of nitrogen fertilizer rates and bio-fertilizer kinds of fresh and dry weights of leaves and roots (g)/plant on tuberose plants during the two seasons.

\begin{tabular}{|c|c|c|c|c|c|c|c|c|}
\hline & \multicolumn{2}{|c|}{$\begin{array}{l}\text { Fresh weight of } \\
\text { leaves (g)/plant }\end{array}$} & \multicolumn{2}{|c|}{$\begin{array}{l}\text { Dry weight of } \\
\text { leaves (g)/plant }\end{array}$} & \multicolumn{2}{|c|}{$\begin{array}{l}\text { Fresh weight of } \\
\text { root (g)/plant }\end{array}$} & \multicolumn{2}{|c|}{$\begin{array}{l}\text { Dry weight of root } \\
\text { (g)/plant }\end{array}$} \\
\hline & $\begin{array}{c}1^{\text {st }} \\
\text { season }\end{array}$ & $\begin{array}{c}2^{\text {nd }} \\
\text { season }\end{array}$ & $\begin{array}{c}1^{\text {st }} \\
\text { season }\end{array}$ & $\begin{array}{c}2^{\text {nd }} \\
\text { season }\end{array}$ & $\begin{array}{c}1^{\text {st }} \\
\text { season }\end{array}$ & $\begin{array}{c}2^{\text {nd }} \\
\text { season }\end{array}$ & $\begin{array}{c}1^{\text {st }} \\
\text { season }\end{array}$ & $\begin{array}{c}2^{\text {nd }} \\
\text { season }\end{array}$ \\
\hline $50 \% N+S$ & 24.7 & 25.7 & 4.37 & 4.00 & 51.3 & 53.0 & 10.9 & 11.9 \\
\hline $50 \% N+Z$ & 26.3 & 29.3 & 4.77 & 4.73 & 55.0 & 60.0 & 12.2 & 12.7 \\
\hline $50 \% N+S * Z$ & 29.7 & 34.3 & 5.23 & 5.80 & 66.0 & 70.3 & 15.3 & 15.6 \\
\hline $75 \%$ N + S & 32.3 & 36.3 & 5.83 & 6.43 & 77.7 & 82.3 & 17.3 & 18.4 \\
\hline $75 \% N+Z$ & 36.3 & 40.7 & 6.23 & 7.07 & 85.3 & 89.0 & 18.7 & 19.8 \\
\hline $75 \% N+S * Z$ & 43.7 & 46.7 & 6.70 & 7.93 & 93.7 & 99.7 & 20.4 & 22.0 \\
\hline $100 \% \mathrm{~N}$ & 39.0 & 41.3 & 5.97 & 6.90 & 92.7 & 96.0 & 20.2 & 21.2 \\
\hline LSD. at $5 \%$ & 1.5 & 1.1 & 0.18 & 0.22 & 1.3 & 2.1 & 0.3 & 0.4 \\
\hline LSD. at $1 \%$ & 2.1 & 1.6 & 0.25 & 0.31 & 1.9 & 2.9 & 0.5 & 0.6 \\
\hline
\end{tabular}

$\mathrm{N}=$ nitrogen, $\mathrm{S}=$ Azospirillum lipoferum, $\mathrm{Z}=$ Azotobacter chrococcoum and $\mathrm{S} * \mathrm{Z}=$ Azospirillum lipoferum + Azotobacter chrococcoum.

\section{Dry weight of leaves (g)/plant:}

Data illustrated in Table (4) reveal that, there were obvious effects of mineral nitrogen and bio-fertilizers on dry weight of leaves/plant of tuberose plants. The highest values recorded with the treatments of mineral nitrogen at $75 \%$ plus the dual inoculation Azospirillum + Azotobacter, with highly significant differences compared with other treatments and control (100\% mineral nitrogen) in both seasons. The lowest values in this regard were reported generally in case of $50 \%$ mineral nitrogen plus inoculation with Asospirillum in both seasons of study. Similarly, the effect of nitrogen fertilizer on dry weight of leaves of tuberose was studied by (Nain et al., 2018). While the positive response of herb dry weight by using nitrogen fixing bacteria was pointed out by Soliman et al. (2009) on French basil (Ocimim bacilicum, L.).

\section{Fresh weight of root (g)/plant:}

Data in Table (4) show that, the combined treatment of mineral nitrogen at 75\% plus the dual inoculation Azospirillum + Azotobacter, resulted in the highest and highly significant value over the other treatments and control $(100 \%$ mineral nitrogen) with non-significant difference in the first season, and highly significant in the second one. These results agree with those obtained by Khalaj et al. (2012) on tuberos and Amin (1997) on coriander, fennel, and caraway.

\section{Dry weight of root (g)/plant:}

Data presented in Table (4) show that, there were highly significant effects due to the treatments, in most cases. Mineral nitrogen at $75 \%$ plus the dual inoculation Azospirillum + Azotobacter, gave the highest dry weight followed by $100 \%$ mineral nitrogen (control) during the two seasons, but with non-significant difference, between them in the first season. Furthermore, the differences between the combined treatment of mineral nitrogen at $75 \%$ plus the dual inoculation Azospirillum + Azotobacter and other treatments were highly significant.

\section{Florets characters:}

\section{Number of florets/spike:}

According to data tabulated in Table (5) on number of florets/spike as affected by mineral nitrogen and bio-fertilization treatments, it could be concluded that, the highest effects were observed with the treatment of $100 \%$ mineral nitrogen (control), followed by mineral nitrogen at $75 \%$ plus the dual inoculation Azospirillum + Azotobacter, with non-significant difference between them in the $1^{\text {st }}$ and $2^{\text {nd }}$ seasons, respectively. The lowest values in this connection were reported generally in case of $50 \%$ mineral nitrogen plus inoculation with Asospirillum in both seasons. 
Table 5. Effect of nitrogen fertilizer rates and bio-fertilizer kinds on number of floret and floret diameter on tuberose plants during the two seasons.

\begin{tabular}{|c|c|c|c|c|}
\hline & \multicolumn{2}{|c|}{ Number of florets/plant } & \multicolumn{2}{|c|}{ Floret diameter $(\mathrm{cm})$} \\
\hline & $1^{\text {st }}$ season & $2^{\text {nd }}$ season & $1^{\text {st }}$ season & $2^{\text {nd }}$ season \\
\hline $50 \% \mathrm{~N}+\mathrm{S}$ & 19.00 & 20.67 & 2.93 & 3.02 \\
\hline $50 \% N+Z$ & 19.33 & 21.67 & 3.01 & 3.12 \\
\hline $50 \% N+S * Z$ & 20.67 & 22.67 & 3.14 & 3.27 \\
\hline $75 \% N+S$ & 24.33 & 24.33 & 3.22 & 3.46 \\
\hline $75 \% N+Z$ & 25.00 & 25.00 & 3.40 & 3.54 \\
\hline $75 \% N+S * Z$ & 26.33 & 27.67 & 3.54 & 3.63 \\
\hline $100 \% \mathrm{~N}$ & 26.67 & 28.00 & 3.32 & 3.49 \\
\hline LSD. at $5 \%$ & 1.11 & 0.85 & 0.04 & 0.05 \\
\hline LSD. at $1 \%$ & 1.56 & 1.20 & 0.05 & 0.07 \\
\hline
\end{tabular}

$\mathrm{N}=$ nitrogen, $\mathrm{S}=$ Azospirillum lipoferum, $\mathrm{Z}=$ Azotobacter chrococcoum and $\mathrm{S} * \mathrm{Z}=$ Azospirillum lipoferum + Azotobacter chrococcoum.

These results agree with those obtained by Khalaj et al. (2012) and Barman et al (2003) on tuberose.

\section{Floret diameter:}

The effect of mineral nitrogen fertilization and bio-fertilization kinds on floret diameter of tuberose plants was recorded in Table (5). The results reveal that, there were effects due to the treatments. Mineral nitrogen at $75 \%$ plus the dual inoculation Azospirillum + Azotobacter, gave the highest diameter with highly significant differences comparing with the other interaction treatments and $100 \%$ mineral nitrogen (control), during the two seasons. These results were in harmony with those reported by Patel (2005) on tuberose and Attia et al. (2005) on Gladiolus grandiflorus.

\section{Fresh weight of spike (g)/plant:}

Regarding the effect of nitrogen fertilizer rates and biofertilizer on the fresh weight of spike (g)/plant, the data illustrated in Table (6) reveal that, there were highly significant effects of the treatments on the fresh weight. The highest value was recorded with the treatment of mineral nitrogen at $75 \%$ plus the dual inoculation Azospirillum + Azotobacter, comparing with the other treatments and control $(100 \%$ mineral nitrogen), in both seasons. On the other hand, there was non-significant difference between mineral nitrogen at $75 \%$ plus the dual inoculation Azospirillum + Azotobacter and treatment with $100 \%$ mineral nitrogen (control) in the first season. The lowest values in this connection were reported generally in case of $50 \%$ mineral nitrogen plus inoculation with Asospirillum in both seasons These results were in parallel with those obtained by Patel (2005) on tuberose as affected by nitrogen fertilizer and Amin (1997) on coriander (Coriandrum sativum), fennel (Feoniculum vulgare), and caraway (Carum carvi) as influenced by biofertilizers.

\section{Dry weight of spike (g)/plant:}

Regarding tabulated data in Table (6) it may be noticed that, the combination treatments between different doses of mineral nitrogen fertilizers and bacteria strains affected dry weight of spike (g)/plant in both seasons. The heaviest and highly significant dry weight recorded with mineral nitrogen at $75 \%$ plus the dual inoculation Azospirillum + Azotobacter, treatment compared with the $100 \%$ mineral nitrogen (control) and other treatments, during the two seasons.

\section{Length of spike $(\mathrm{cm})$ :}

Data in Table (6) showed that, the interaction treatment of mineral nitrogen at 75\% plus the dual inoculation Azospirillum + Azotobacter, resulted in the tallest spike, with highly significant differences comparing with the other treatments and control (100\% mineral nitrogen) treatment. These results were repeated in the second season, as the results of the first one. 
Table 6. Effect of nitrogen fertilizer rates and bio-fertilizer kinds on number of floret, floret diameter, length of spike and longevity (days) of tuberose plants during the two seasons of 2017 and 2018.

\begin{tabular}{|c|c|c|c|c|c|c|c|c|}
\hline & \multicolumn{2}{|c|}{$\begin{array}{l}\text { Fresh weight of } \\
\text { spike/plant }\end{array}$} & \multicolumn{2}{|c|}{$\begin{array}{c}\text { Dry weight of } \\
\text { spike/plant }\end{array}$} & \multicolumn{2}{|c|}{$\begin{array}{l}\text { Length of spike } \\
\text { (cm) }\end{array}$} & \multicolumn{2}{|c|}{ Longevity (days) } \\
\hline & $1^{\text {st }}$ season & $\begin{array}{c}1^{\text {st }} \\
\text { season }\end{array}$ & $\begin{array}{c}1^{\text {st }} \\
\text { season }\end{array}$ & $\begin{array}{c}1^{\text {st }} \\
\text { season }\end{array}$ & $\begin{array}{c}1^{\text {st }} \\
\text { season }\end{array}$ & $\begin{array}{c}2^{\text {nd }} \\
\text { season }\end{array}$ & $\begin{array}{c}1^{\text {st }} \\
\text { season }\end{array}$ & $\begin{array}{c}2^{\text {nd }} \\
\text { season }\end{array}$ \\
\hline $50 \% N+S$ & 89.7 & 101.0 & 22.5 & 22.4 & 13.33 & 16.00 & 13.53 & 14.07 \\
\hline $50 \% N+Z$ & 105.3 & 115.3 & 24.7 & 25.4 & 15.00 & 17.67 & 14.10 & 14.47 \\
\hline $50 \% N+S * Z$ & 127.7 & 132.0 & 29.4 & 30.2 & 18.67 & 19.00 & 14.73 & 14.77 \\
\hline $75 \% \mathrm{~N}+\mathrm{S}$ & 146.3 & 150.0 & 32.9 & 33.9 & 18.33 & 19.67 & 14.97 & 14.93 \\
\hline $75 \% \mathrm{~N}+\mathrm{Z}$ & 154.0 & 167.0 & 37.0 & 37.7 & 20.33 & 21.67 & 14.60 & 15.40 \\
\hline $75 \% N+S * Z$ & 183.0 & 199.7 & 43.4 & 44.3 & 22.33 & 23.67 & 15.77 & 16.67 \\
\hline $100 \% \mathrm{~N}$ & 179.3 & 194.3 & 40.3 & 42.9 & 20.67 & 21.67 & 14.70 & 14.93 \\
\hline LSD. at 5\% & 4.5 & 2.5 & 1.7 & 0.6 & 0.94 & 0.84 & 0.69 & 0.60 \\
\hline LSD. at $1 \%$ & 6.3 & 3.6 & 2.4 & 0.9 & 1.32 & 1.18 & 0.97 & 0.84 \\
\hline
\end{tabular}

$\mathrm{N}=$ nitrogen, $\mathrm{S}=$ Azospirillum lipoferum, $\mathrm{Z}=$ Azotobacter chrococcoum and $\mathrm{S} * \mathrm{Z}=$ Azospirillum lipoferum + Azotobacter chrococcoum.

The lowest values in this connection were reported generally in case of $50 \%$ mineral nitrogen plus inoculation with Asospirillum in both seasons. These results agree with those reported by Khalaj et al. (2012) on tuberose and Attia et al (2005) on Gladiolus grandiflorus.

\section{Longevity (days):}

Data regarding the effect of mineral nitrogen levels and different kinds of biofertilization on longevity (days) were presented in Table (6). The treatments had pronounced influences on longevity. The differences between majority of treatments were highly significant. The superior effect obtained from the combined treatment of mineral nitrogen at $75 \%$ plus the dual inoculation Azospirillum + Azotobacter, followed by mineral nitrogen at $75 \%$ plus inoculation with Azotobacter treatment, with highly significant effects during $2^{\text {nd }}$ season. Furthermore, the treatment of mineral nitrogen at $75 \%$ plus the dual inoculation Azospirillum + Azotobacter, recorded best results more than $100 \%$ mineral nitrogen (control) with highly significant differences during both seasons.

These results agree with those obtained by Kumar et al. (2017) and Ali et al. (2014) on gladiolus.

\section{Chemical constituents:}

\section{Nitrogen percentage:}

The effect of mineral nitrogen fertilization rates and bio-fertilization kinds on nitrogen percentage of tuberose leaves was recorded in Table (7). The results reveal that, there were clear effects due to different treatments. Mineral nitrogen at $75 \%$ plus the dual inoculation Azospirillum + Azotobacter, gave the highest and highly significant percentage of nitrogen compared to the other treatments, in both seasons. In the same way, the combined treatment of mineral nitrogen at $75 \%$ plus the dual inoculation Azospirillum + Azotobacter, recorded an increase over the $100 \%$ mineral nitrogen (control) treatment with highly significant differences during the first and second seasons, respectively. These results were in harmony with those revealed by Almaliotis et al. (1997) who indicated that nitrogen content of upper and basal leaves of peach increased by increasing $\mathrm{N}$ level of nutrient solution and Gomaa and Abou-Aly (2001) on anise (Pimpinella anisum).

\section{Phosphorus percentage:}

Regarding the effect of mineral nitrogen fertilizer rates and bio-fertilization kinds on phosphorus percentage of tuberose leaves, the data illustrated in Table (7) reveal that, there were obvious effects in this regard. The highest values were recorded with the 
Table 7. Effect of nitrogen fertilizer rates and bio-fertilizer kinds on number of $\mathrm{N}, \mathrm{P}, \mathrm{K}$, carbohydrates percentage and chlorophyll $a$ and $b$ content in tuberose plants during the two seasons.

\begin{tabular}{|c|c|c|c|c|c|c|c|c|c|c|}
\hline & \multicolumn{2}{|c|}{ N\% } & \multicolumn{2}{|c|}{ P\% } & \multicolumn{2}{|c|}{ K\% } & \multicolumn{2}{|c|}{ Chlorophyll A } & \multicolumn{2}{|c|}{ Chlorophyll B } \\
\hline & $\begin{array}{c}1^{\text {st }} \\
\text { season }\end{array}$ & $\begin{array}{c}2^{\text {nd }} \\
\text { season } \\
\end{array}$ & $\begin{array}{c}1^{\text {st }} \\
\text { season } \\
\end{array}$ & $\begin{array}{c}2^{\text {nd }} \\
\text { season } \\
\end{array}$ & $\begin{array}{c}1^{\text {st }} \\
\text { season } \\
\end{array}$ & $\begin{array}{c}2^{\text {nd }} \\
\text { season } \\
\end{array}$ & $\begin{array}{c}1^{\text {st }} \\
\text { season }\end{array}$ & $\begin{array}{c}2^{\text {nd }} \\
\text { season } \\
\end{array}$ & $\begin{array}{c}1^{\text {st }} \\
\text { season } \\
\end{array}$ & $\begin{array}{c}2^{\text {nd }} \\
\text { season }\end{array}$ \\
\hline $50 \% \mathrm{~N}+\mathrm{S}$ & 1.55 & 1.58 & 0.360 & 0.370 & 1.96 & 1.99 & 0.823 & 0.873 & 0.573 & 0.633 \\
\hline $50 \% \mathrm{~N}+\mathrm{Z}$ & 1.63 & 1.68 & 0.393 & 0.410 & 2.06 & 2.15 & 0.850 & 0.907 & 0.617 & 0.673 \\
\hline $50 \% N+S * Z$ & 1.72 & 1.77 & 0.437 & 0.450 & 2.17 & 2.30 & 0.873 & 0.943 & 0.653 & 0.717 \\
\hline $75 \% \mathrm{~N}+\mathrm{S}$ & 1.81 & 1.88 & 0.447 & 0.470 & 2.40 & 2.47 & 0.927 & 0.970 & 0.657 & 0.737 \\
\hline $75 \% \mathrm{~N}+\mathrm{Z}$ & 1.84 & 1.92 & 0.463 & 0.487 & 2.57 & 2.65 & 0.953 & 1.013 & 0.757 & 0.767 \\
\hline $75 \% N+S * Z$ & 1.94 & 2.01 & 0.537 & 0.543 & 2.76 & 2.82 & 1.037 & 1.077 & 0.727 & 0.827 \\
\hline $100 \% \mathrm{~N}$ & 1.90 & 1.96 & 0.503 & 0.533 & 2.71 & 2.78 & 1.007 & 1.073 & 0.703 & 0.797 \\
\hline LSD. at $5 \%$ & 0.016 & 0.017 & 0.007 & 0.009 & 0.03 & 0.03 & 0.007 & 0.018 & 0.078 & 0.017 \\
\hline LSD. at $1 \%$ & 0.023 & 0.024 & 0.010 & 0.012 & 0.04 & 0.04 & 0.010 & 0.025 & 0.109 & 0.024 \\
\hline
\end{tabular}

$\mathrm{N}=$ nitrogen, $\mathrm{S}=$ Azospirillum lipoferum, $\mathrm{Z}=$ Azotobacter chrococcoum and $\mathrm{S} * \mathrm{Z}=$ Azospirillum lipoferum + Azotobacter chrococcoum.

treatments of mineral nitrogen at $75 \%$ plus the dual inoculation Azospirillum + Azotobacter, with highly significant differences compared with other treatments in both seasons, and with $100 \%$ mineral nitrogen (control) treatment in the first season. The same trend was reported by Patel (2005) on tuberose and Gomaa and Abou-Aly (2001) on anise.

\section{Potassium percentage:}

Data presented in Table (8) show the effect of mineral nitrogen fertilizer rates and biofertilizers on potassium percentage. The treatment of mineral nitrogen at $75 \%$ plus the dual inoculation Azospirillum + Azotobacter, resulted in the highest and highly significant value comparing with the other treatments and 100\% mineral nitrogen (control) treatment during the two seasons, but the lowest values in this connection were reported generally in case of $50 \%$ mineral nitrogen plus inoculation with Asospirillum in both seasons of study. In harmony with these results were those revealed by Khalaj et al. (2012) on tuberos and Gomaa and Abou-Aly (2001) on anise.

\section{Chlorophyll A percentage:}

The effect of the treatments with mineral nitrogen fertilization rates and biofertilization kinds on chlorophyll A percentage of tuberose leaves was recorded in Table (7). The results reveal that, there were pronounced effects due to applying different treatments. The differences between combined treatments were highly significant. The highest percentage of chlorophyll A obtained from the treatment of mineral nitrogen at $75 \%$ plus the dual inoculation Azospirillum + Azotobacter, furthermore, it gave the highest percentage over the control treatment with highly significant in the first season and non-significant in the second one. These results agree with those obtained by Khalaj et al. (2012) on tuberos and Attia et al. (2005) on Gladiolus grandiflorus.

\section{Chlorophyll B percentage:}

As for the treatments with mineral nitrogen fertilizer levels and different kinds of bio-fertilization on chlorophyll B percentage, the data registered in Table (7) show that, the treatment of mineral nitrogen at $75 \%$ plus the dual inoculation Azospirillum + Azotobacter, resulted in the highest value with highly significant effect in both seasons, in most cases. On the same way, this treatment gave the highest percentage over the $100 \%$ mineral nitrogen (control) treatment with non-significant in the first season and highly significant in second one, respectively.

\section{Carbohydrates percentage:}

Data tabulated in Table (8), show that the highest effects of mineral nitrogen fertilization rates and different kinds of bio- 
Table 8. Effect of nitrogen fertilizer rates and bio-fertilizer kinds on carbohydrates and essential oil percentages of tuberose plants during the two seasons.

\begin{tabular}{|c|c|c|c|c|}
\hline & \multicolumn{2}{|c|}{ Carbohydrate \% } & \multicolumn{2}{|c|}{ Essential oil percentage } \\
\hline & $1^{\text {st }}$ season & $2^{\text {nd }}$ season & $1^{\text {st }}$ season & $2^{\text {nd }}$ season \\
\hline $50 \% \mathrm{~N}+\mathrm{S}$ & 16.86 & 17.55 & 0.0250 & 0.0247 \\
\hline $50 \% N+Z$ & 17.09 & 17.94 & 0.0249 & 0.0251 \\
\hline $50 \% N+S^{*} Z$ & 17.43 & 18.25 & 0.0252 & 0.0255 \\
\hline $75 \% N+S$ & 17.57 & 18.67 & 0.0254 & 0.0258 \\
\hline $75 \% N+Z$ & 17.92 & 18.92 & 0.0256 & 0.0258 \\
\hline $75 \% N+S * Z$ & 19.23 & 20.42 & 0.0268 & 0.0264 \\
\hline $100 \% \mathrm{~N}$ & 18.84 & 19.18 & 0.0261 & 0.0262 \\
\hline LSD. at $5 \%$ & 0.14 & 0.23 & & \\
\hline LSD. at $1 \%$ & 0.19 & 0.32 & & \\
\hline
\end{tabular}

$\mathrm{N}=$ nitrogen, $\mathrm{S}=$ Azospirillum lipoferum, $\mathrm{Z}=$ Azotobacter chrococcoum and $\mathrm{S} * \mathrm{Z}=$ Azospirillum lipoferum + Azotobacter chrococcoum.

fertilization on carbohydrates percentage in tuberose leaves were observed with the mineral nitrogen at $75 \%$ plus the dual inoculation Azospirillum + Azotobacter, followed by $100 \%$ mineral nitrogen (control) with highly significant difference between them in both seasons. These results agree with those reported by Khalaj et al. (2012) on tuberose and Attia et al. (2005) on Gladiolus grandiflorus.

\section{Essential oil percentage:}

According to data presented in Table (8) on essential oil percentage as affected by the treatments between mineral nitrogen fertilizer ratios and bio-fertilization kinds, it could be observed that, the highest result recorded with the treatment of mineral nitrogen at $75 \%$ plus the dual inoculation Azospirillum + Azotobacter, comparing with all treatments and followed by $100 \%$ mineral nitrogen (control) during the two seasons. This treatment yielded 0.0268 and $0.0264 \%$, in the first and second seasons, respectively. These results were in harmony with those revealed by Soliman et al. (2009) on volatile oil yield of french basil (Ocimim bacilicum, L.).

The correlation between longevity (day) and some flowering and vegetative characters:

The data in Table (9) show that, there were highly significant positive correlations between longevity (day) and all of floret diameter, length of spike, fresh and dry weights of spike, fresh and dry weights of leaves characters, under the treatments of mineral nitrogen fertilizer and bio-fertilizers, during the two seasons.

From the previous results we can indicate that, the increase in longevity (day) of the vase flowers, reflect positively the raise in floret diameter, spike length, fresh and dry weight of spike (g)/plant and fresh and dry weight of leaves (g)/plant under the treatments of mineral nitrogen fertilizer ( 50 , 75 and $100 \% \quad \mathrm{~N})$ with bio fertilizers (Azospirillum and Azotobacter).

\section{Recommendation:}

From the aforementioned results, it could be recommended to treat tuberose plants (Polianthes tuberosa L.) grown in sandy soils with $75 \% \mathrm{~N}+$ Azospirillum lipoferum + Azotobacter chrococcoum to obtain the highest parameters of vegetative growth characters, floral characters, the longevity of cut flower spikes (days) as well as the content of essential oil percentage in flowers.

\section{REFERENCES}

Alan, O.; Gunen, Y.; Ceylan, S. and Gunen, E. (2007). Effect of nitrogen applications on flower yield, some quality characteristics and leaf mineral content in tuberose (Polianthes tuberosa L.). Ege Tarimsal Arastirma Enstitusu Mudurlugu, Izmir, Turkey: Aegean Agric. Res. Ins. Direc., 17(1):43-57. 
Table 9. Effect of $\mathbf{N}$ fertilizer and bio fertilizers treatments on the correlation measure between longevity (day) with some flowering and vegetative characters during the two seasons.

\begin{tabular}{lccccc}
\hline \multicolumn{1}{c}{ Flowering characters } & \multicolumn{3}{c}{ Longevity (day) } \\
& \multicolumn{1}{c}{$\mathbf{1}^{\text {st }}$ season } & \multicolumn{2}{c}{$\mathbf{2}^{\text {nd }}$ season } \\
\hline Floret diameter & 0.963 & $* *$ & 0.966 & $* *$ \\
Length of spike & 0.999 & $* *$ & 0.999 & $* *$ \\
Fresh weight of spike & 0.962 & $* *$ & 0.969 & $* *$ \\
Dry weight of spike & 0.965 & $* *$ & 0.975 & $* *$ \\
Fresh weight of leaves & 0.949 & $* *$ & 0.997 & $* *$ \\
Dry weight of leaves & 0.959 & $* *$ & 0.939 & $* *$
\end{tabular}

Ali, A.; Mehmood, T.; Hussain, R.; Bashir, A.; Raza, S.; Din, N. and Ahmad, A. (2014). Investigation of biofertilizers influence on vegetative growth, flower quality, bulb yield and nutrient uptake in Gladiolus (Gladiolus grandiflorus L.). International Journal of Plant, Animal and Environmental Sciences, 4(1):94-99.

Almaliotis, D; Therios, I. and Karatassiou, M. (1997). Effect of nitrogen fertilization on growth, leaf nutrient concentration and photosynthesis in three peach cultivars. Acta Hort., 449: 529534.

Amin, I.S. (1997). Effect of bio- and chemical fertilization on growth and production of Coriandrum sativum, Foeniculum vulgare and Carum carvi plants. Annals Agric. Sci. Moshtohor, Egypt, 35(4):2327-2334.

Attia, F.A.; Abdou, M.A.H.; Aly, M.K.; Mohey-Eldin, M.M. and Sayed, I.H. (2005). Response of gladiolus plants to some bio-and chemical fertilization treatments: 2- Corms productivity and chemical constituents. Proc. $6^{\text {th }}$ Arabian Conference For Horticulture, Ismailia, Egypt, 246-262.

Barman, D.; Datta, M.; De, L.C. and Banik, S. (2003). Efficacy of phosphatesolubilizing and phytohormone producing bacteria on the growth and yield of tuberose in acid soil of Tripura. Indian Journal of Horticulture, 60(3):303306.
Benschop, M. (1993). Polianthes. In: The Physiology of Flower Bulbs (De Hertogh A., Le Nard M., eds). Elsevier Publ, Amsterdam, the Netherlands. p: 601

Bhonde, S.R.; Sharma, S.B. and Chougule, A. B. (1997). Effect of biofertilizer in combination with nitrogen through organic and inorganic sources on yield and quality of onion. National Hort. Res. Develop. Found., 17(2):1-3 .

Dadarwal, L.R.; Yadav, L.S. and Sindhu, S.S. (1997). Biofertilizer-fertilizer Production Technology: Prospects In. Biotechnological Approaches: In. Soil Microorganisms for Sustainable Crop Production. pp: 323- 337. Scientific Publisher, Jodhpur, India (C.F. Proceeding of Training Course on BioOrganic Farming Systems for Sustainable Agriculture. July, 1997, Cairo, Egypt).

El-Kouny, H.M. (2002). Effect of organic fertilizer in different application rates under salinity stress goudvion on soil and plant. International Symposium and Optimum Resources Utilization in SaltAffected Ecosystems in Arid and Semiarid Regions, 8-11 April 2002, Cairo, Egypt, Le Meridian, Heliopolis Hotel, Abst. Book, pp. 33.

El-Saka, M.M. (1992). Physiological Studies for Increasing The Longevity of Some Flowers. Ph.D. Thesis, Faculty of Agric., Zagazig University, Egypt.

Fayez, M.; Emam, N.F. and Makboul, H.E. 
(1985). The possible use of nitrogen fixing Azospirillum as biofertilizer for wheat plants. Egypt. J. Microbiol., 20(2):190-206.

Gomaa, A.O. and Abou-Aly, H.E. (2001). Efficiency of bioferitlization in the presence of both inorganic and organic fertilizers on growth, yield and chemical constituents of anise plant (Pimpinella anisum L.). Proc. $5^{\text {th }}$ Arabian Hort. Conf. March 24-28, Ismailia, Egypt, 11:49-62

Herbert, D.; Philips, P.J. and Strange, R.E. (2005). Determination of total carbohydrates. Methods in Microbiology, 58: 209-344.

Jawaharlal, $\quad$ M.; $\quad$ Arumugam, $\quad$ T.; Bhattacharjee, and Vijayakumar, $\mathrm{M}$. (2006). Tuberose. In: "Advances in Ornamental Horticulture", (S. K. Ed.): Bhattacharjee, S. K. Pointer Publishers, Jaipur, India, 3: 107-132.

Kandeel, A.M.; Naglaa, S.A.T. and Sadek, A.A. (2002). Effect of biofertilizers on the growth, volatile oil yield and chemical composition of Ocimum basilicum L. plant. Annals Agric. Sci., Ain Shams Univ., Cairo, 47(1): 351-371.

Khalaj, M.A.; Edrisi, B. and Amiri, M. (2012). Effect of nitrogen and plant spacing on nutrients uptake, yield and growth of tuberose (Polianthes tuberosa L.). Journal of Ornamental and Horticultural Plants, 2 (1): 45-54.

Kumar, K.; Singh, C.N.; Beniwal, V.S.; Pinder, R. and Poonia, R.S. (2017). Effect of nitrogen fertilizer on different attributes of gladiolus (Gladiolus grandiflorous L.) cv. American Beauty. International Journal of Environment, Agriculture and Biotechnology, 2(1):1-3.

Majid, B.; Hassan, S. and Saeid, E. (2012). Growth and flowering of tuberose as affected by adding natural Zeolite to the culture medium. J. of Plant Nutr., 35(10): 1491-1496.
Mazumdar, B.C. and Majumder, K. (2003). Methods of Physiochemical Analysis of Fruits. Daya Publishing House Delhi, India.

Nain, S.; Beniwal, B.S. and Dalal, R.P.S. (2018). Studies on the effect of nutrients (nitrogen and phosphorus) on growth and development of tuberose (Polianthes tuberosa) cv. Prajwal under Haryana Condition. Int. J. Pure App. Biosci., 6(2): 1554-1560.

Patel, M.M. (2005). Effect of nitrogen, phosphorus and spacing on growth and flowering in tuberose (Polianthes tuberosa L.) cv. 'Single'. Department of Horticulture, College of Agriculture, Navsari Agricultural University, Navsari - 396 450, Gujarat State.

Qureshi, M.W. (2007). Influence of Biofertilizers on Growth and Flowering of Tuberose (Polianthes tuberosa L.) cv. Mexican Single. M. Sc. Thesis, Fac. Agric., Jawaharlal Nehru Technological Univ., Jabalpur., India.

Raddy, T.Y. and Reddi, G.H.S. (2002). Principles of Agronomy - Kalyani Publishers, $3^{\text {rd }}$ ed., pp:526.

Rakthaworn, P.; Dilokkunanant, U.; Sukkatta, U.; Vajrodaya, S.; Haruethaitanasan, V.; Pitpiangchan, P. and Punjee, P. (2009). Extraction methods for tuberose oil and their chemical components. Kasetsart J. (Nat. Sci.) 43: $204-211$.

Soliman, S.G.I.; Harridy, I.M.A. and Ismail, E.G. (2009). Response of French basil plants (Ocimum bacilicum) to nitrogen fixing bacteria. J. Agric. Sci. Mansoura Univ., 34(5): 5137-5150.

Sperenat, M. (1990). Nitrogen Fixing Organisms. P.5. Chapman and Hall, London.

Steel, R.G.D. and Torrie, S.H. (1980). Principles and Procedure of Statistics. Second Edition, Mc-Grow Hill Inc. 


\section{استجابة نباتات التيبروز للتسميد الحيوي والكيماوي وتأثيرهما علي النمو الخضري و الإزهار

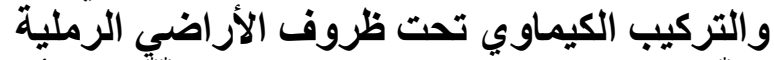

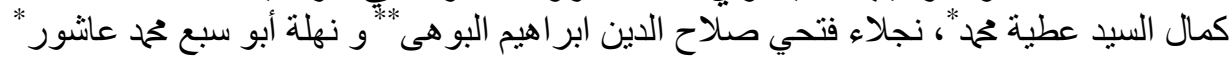

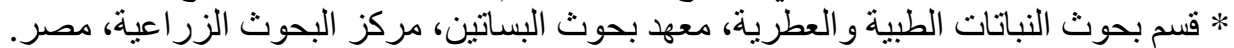 *** قسم بحوث نباتات الزينة وتنسيق الحدائق، معهد بحوث البساتين، مركز البحوث الزئن الزية الزية، مصر.}

أجريت تجربة حقلية بالمزر عة التجريبية لمحطة البحوث الزر اعبة بالقصاصين، مركز البحوث الزر اعبة، محافظة

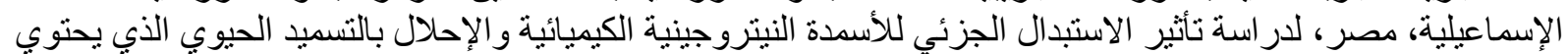

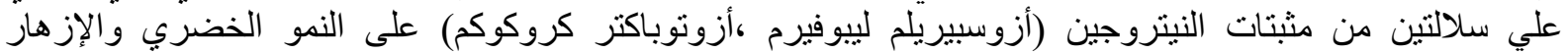

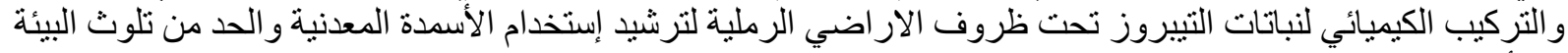

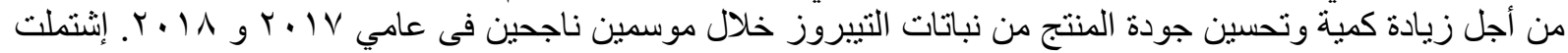

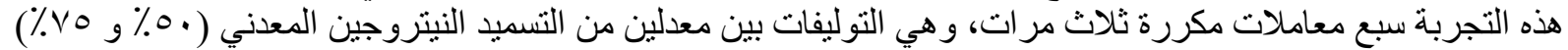

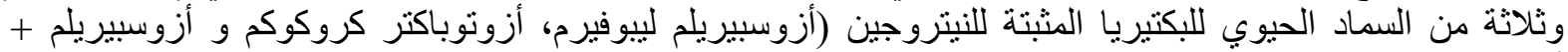

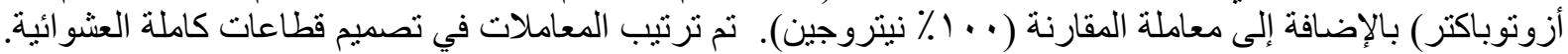

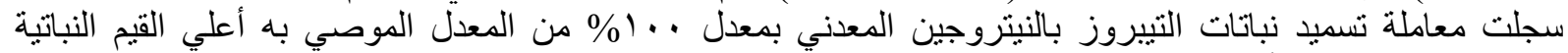

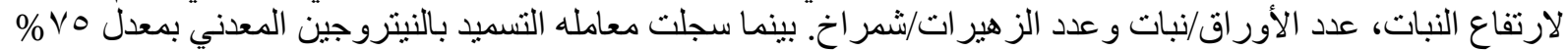

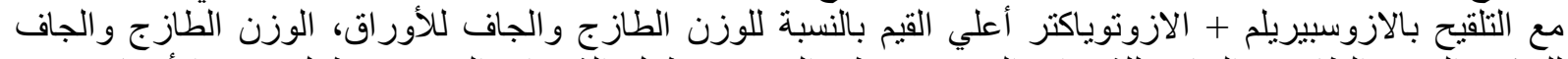

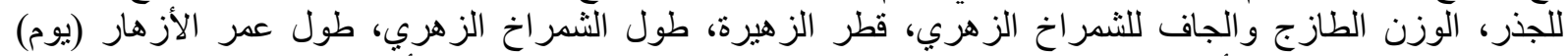

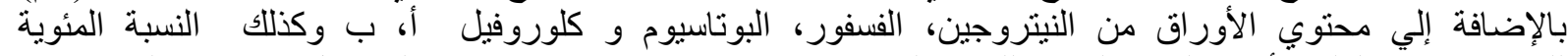

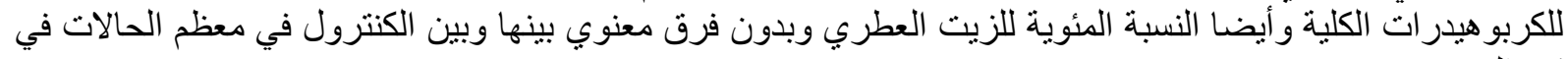

